\title{
Associations between chronic comorbidity and exacerbation risk in primary care patients with COPD
}

\author{
Janine A. M. Westerik', Esther I. Metting' ${ }^{2}$, Job F. M. van Boven², Waling Tiersma'1, Janwillem W. H. Kocks² \\ and Tjard R. Schermer ${ }^{*}$
}

\begin{abstract}
Background: COPD often coexists with chronic conditions that may influence disease prognosis. We investigated associations between chronic (Co)morbidities and exacerbations in primary care COPD patients.

Method: Retrospective cohort study based on 2012-2013 electronic health records from 179 Dutch general practices. Comorbidities from patients with physician-diagnosed COPD were categorized according to International Classification of Primary Care (ICPC) codes. Chi-squared tests, uni- and multivariable logistic, and Cox regression analyses were used to study associations with exacerbations, defined as oral corticosteroid prescriptions.

Results: Fourteen thousand six hundred three patients with COPD could be studied (mean age 67 (SD 12) years, 53\% male) for two years. At baseline 12,826 (88\%) suffered from $\geq 1$ comorbidities, $3263(22 \%)$ from $\geq 5$. The most prevalent comorbidities were hypertension (35\%), coronary heart disease (19\%), and osteoarthritis (18\%). Several comorbidities showed statistically significant associations with frequent (i.e., $\geq 2 / y e a r)$ exacerbations: heart failure (odds ratio [OR], 95\% confidence interval: 1.72; 1.38-2.14), blindness \& low vision (OR 1.46; 1.21-1.75), pulmonary cancer (OR 1.85; 1.28-2.67), depression 1.48; 1.14-1.91), prostate disorders (OR 1.50; 1.13-1.98), asthma (OR 1.36; 1.11-1.70), osteoporosis (OR 1.41; 1.11-1.80), diabetes (OR 0.80; 0.66-0.97), dyspepsia (OR 1.25; 1.03-1.50), and peripheral vascular disease (OR 1.20; 1.00-1.45). From all comorbidity categories, having another chronic respiratory disease beside COPD showed the highest risk for developing a new exacerbation (Cox hazard ratio 1.26; 1.17-1.36).
\end{abstract}

Conclusion: Chronic comorbidities are highly prevalent in primary care COPD patients. Several chronic comorbidities were associated with having frequent exacerbations and increased exacerbation risk.

\section{Background}

Although nowadays healthcare systems are largely configured to manage individual diseases rather than multimorbidity, there is an increasing awareness of the importance of comorbidities in patients with chronic conditions [1]. Chronic obstructive pulmonary disease (COPD), a prevalent chronic respiratory condition, is a major cause of morbidity and mortality worldwide [2]. In the past decade several studies have shown that COPD often coexists with other diseases, [3,4] and that comorbidity is associated with poorer clinical outcomes

\footnotetext{
* Correspondence: tjard.schermer@radboudumc.nl

${ }^{1}$ Department of Primary and Community Care, Radboud University Medical Center, 117-ELG, Geert Grooteplein Noord 21, Nijmegen 6525 EZ, The Netherlands

Full list of author information is available at the end of the article
}

$[4,5]$. Some of these comorbidities arise independently of COPD, whereas others may be causally related, either through shared risk factors (smoking, aging) or shared pathophysiology, as a complication of COPD, or due to medication side effects.

Several associations between COPD and particular comorbidities have been shown. Cardiovascular disease, metabolic syndrome, skeletal muscle dysfunction, osteoporosis, depression and lung cancer are all highly prevalent among patients with any severity of COPD, and cross-sectional studies have shown their significant impact on patients' health-related quality of life $[2,6,7]$. Most of the research on comorbidity in COPD comes from studies in secondary care populations, thus representing patients in the more severe part of the COPD severity spectrum [4]. However, in most developed countries, the vast 
majority of patients with COPD are managed in primary care. Studies performed in general practice settings report that 21 to $74 \%$ of patients with COPD suffer from two or more additional chronic diseases $[6,8]$.

As COPD is a progressive disease, factors that influence its prognosis are important to consider when managing patients. Since exacerbation frequency is a known predictor of COPD progression, [2] it is important to know what the potential impact of comorbidities on the risk of exacerbations is. Recently Putcha et al.reported a model in which the number of comorbid conditions predicted dyspnea and exacerbation risk [9]. This prediction model does, however, not take into account which particular comorbid conditions are associated with exacerbation risk. Other previous studies have predominantly looked at mortality as the outcome of interest, $[5,10,11]$ but from a patient management perspective it is important that physicians consider comorbidities that influence potentially modifiable prognostic factors like exacerbation rate in their treatment decisions. Therefore, the aim of the current study was to explore associations between a wide range of comorbid chronic conditions and exacerbation risk in a real-life cohort of primary care patients with COPD.

\section{Methods}

\section{Design and dataset}

The study used routine data from a general practice database from the Department of Primary and Community Care at the Radboud University Medical Center, Nijmegen, the Netherlands. De-identified electronic medical records from primary care patients diagnosed with COPD from 179 general practices in the eastern part of the Netherlands were available in the database.

For each registered subject, the following data were extracted: age, sex, all diagnoses using the International Classification of Primary Care (ICPC), extended with Dutch ICPC sub-codes, [12] and all prescribed medication. ICPC-2 or ICD10 coding data were recoded into ICPC-1. Medication prescriptions (i.e., prescription start and end dates, dosage, frequency, and duration) were extracted and categorized using the Anatomical Therapeutic Chemical (ATC) classification system [13]. For the current study only the data on prescriptions for oral corticosteroids were used.

\section{Study population}

Subjects aged $\geq 40$ years were included in the study population when they had physician-diagnosed COPD (as labeled with ICPC code R95 in the electronic medical record) before or during the study period. Asthma (ICPC R96) in addition to the COPD code was not an exclusion criterion. The follow-up period covered the years 2012 and 2013. The observation period for patients terminated either at the end of the study period (31 December 2013), or when a subject died or deregistered from the practice.

\section{Comorbidities}

The selection of chronic comorbid diseases studied was based on existing literature $[1,14]$, the authors' clinical expertise and expert opinions (Nielen MM, Spronk I, Davids R, Korevaar JC, Poos MJ, Hoeymans N, Opstelten W, van der Sande MAB, Biermans MCJ, Schellevis FG, RA V: A new method for estimating morbidity rates based on routine electronic medical records in primary care, submitted). We considered all chronic diseases as comorbidities, regardless whether the disease had been diagnosed before the COPD diagnosis or thereafter. Apart from all 'obligatory' chronic diseases we also included several recurrent diseases (i.e., depression, anxiety, anemia, dyspepsia, urinary tract infection) which could potentially influence COPD outcomes. After reaching consensus about these recurrent comorbidities within the research team, ICPC (sub)codes were linked (see Appendix 1). Selection of the recurrent comorbidities in our population was based on the patient's history in terms of these particular ICPC codes. To define whether a history of ICPC codes was relevant or irrelevant for the aim of the study, we added specific selection criteria based on published clinical guidelines for the respective diseases (see Appendix 1).

Finally, a total of 82 chronic comorbid conditions were selected and included in the analyses. The comorbidities were clustered and analyzed based on their ICPC codes into the following 14 categories: respiratory; cardiovascular; digestive; endocrine; metabolic/nutrition; musculoskeletal; neurologic; psychiatric; urogenital; blood (-forming organs)/lymphatics; infectious; eye/ear/skin; non-pulmonary cancer; and pulmonary cancer. Low prevalence categories were merged (see Appendix 2). To restrict ourselves, we focused on conditions with a high prevalence and cardiopulmonary comorbidities (other than COPD) with a lower prevalence ( 7 conditions, see Table 2). High-prevalent comorbidities (19 conditions), further referred to as 'frequent comorbidities', were defined as being present in $\geq 5 \%$ of the study population. This resulted in a total of 26 comorbidities remaining for further analyses.

\section{Outcomes}

The outcomes for the study were (i) prevalence of comorbidities in the study population, (ii) annual rate of exacerbations (dichotomized as $<2$ versus $\geq 2$ exacerbations/year based on the cumulated 2012/13 data), and (iii) time (in days) until first exacerbation. An exacerbation was defined as a prescription of oral corticosteroids (i.e., prednisolone (ATC H02AB06) or prednisone (ATC H02AB07)) with a minimum daily dose of $20 \mathrm{mg}$ for a minimum duration of 5 days and a maximum duration 
of 15 days (based on Dutch GP guidelines for treatment of COPD exacerbations [15]). As there is no consensus in the literature regarding a cut-off to differentiate between relapse of an earlier exacerbation and a new exacerbation, [16] we considered a subsequent predniso(lo)ne prescription after an oral corticosteroid-free interval of $\geq 14$ days since the end-date of the previous prescription as a new exacerbation.

\section{Statistical analysis}

Analyses were performed with SPSS statistical software (version 22, IBM SPSS Statistics, Feltham, Middlesex, UK) and Microsoft Excel 2007 (Microsoft Corporation, Redmond, Washington, US). Statistically significant results were defined as $p<0 \cdot 05$. Patients' baseline characteristics and comorbidity prevalence rates were calculated. We performed Chi-square tests for categorized variables and independent t-tests for continuous variables to analyze differences between the subgroups with $<2$ and $\geq 2$ exacerbations per year.

We explored associations between comorbidities and exacerbation risk using univariable analyses. Hazard ratios for comorbidities were calculated using Cox regression, in which the time variable consisted of time to the first exacerbation. Data from patients who died or were otherwise lost to follow up were right-censored. Subsequently, all frequent and cardiopulmonary comorbidities (Table 2), age, and gender were included as covariates in multivariate Cox regression analyses. The model was reduced through backward exclusion to produce a final model that consisted of only noncollinear, independently associated, statistically significant covariates. The same modeling approach was used for comorbidity categories using all other categories, with age and gender as covariates.

In addition, we performed multivariable logistic regression analyses to calculate odds ratio's (ORs) with the dichotomous indicator variable for exacerbation frequency $(<2$ versus $\geq 2$ exacerbations/year) as the dependent variable. Predictor variables in the logistic models were: all frequent comorbidities, all cardiopulmonary comorbidities, gender, and age. This modeling approach was also used to analyze the 14 categories of comorbidity.

\section{Results}

\section{Study population}

Overall, data of 16,427 subjects diagnosed with COPD were available for analyses. Of these patients, 1824 $(11 \cdot 1 \%)$ were lost to follow-up during the 2-year study period. Reason for loss to follow-up was known for $800(44.5 \%)$ of these patients, with death being the predominant reason. Table 1 shows baseline characteristics of the patients with complete follow-up (i.e., the final study population, $n=14,603)$. Mean (SD) age was $66.5(11 \cdot 5)$ years and $53 \%$ were males. At baseline, $89.1 \%$ of patients suffered from $\geq 1$ chronic comorbid conditions, while $23 \cdot 1 \%$ had $\geq 5$ comorbidities. Most prevalent comorbid conditions were hypertension $(35 \cdot 2 \%)$, coronary heart disease $(19 \cdot 2 \%)$, osteoarthritis $(17 \cdot 6 \%)$, diabetes $(17 \cdot 3 \%)$, and peripheral vascular disease (14.3\%). Table 2 shows the prevalence rates of the frequent and cardiopulmonary comorbidities. Table 3 shows the prevalence of ICPCcategorized comorbidities.

During the 2-year study period the mean number of exacerbations per patient was 0.72 (SD 1.5). $68 \%$ of patients had no exacerbation and $5 \cdot 7 \%$ had $\geq 4$ exacerbations during the study period.

\section{Associations between comorbidities and exacerbation frequency}

Tables 2 and 3 show the univariable associations between comorbidities and comorbidity categories and the exacerbation frequency subgroups, respectively. Overall, patients with one or more comorbid conditions more often had $\geq 2$ exacerbations/year compared to patients without any comorbidity $(5 \cdot 9 \%$ vs $4 \cdot 0 \%$, $p=0 \cdot 001)$. Patients with any other chronic respiratory disease next to their COPD, $(n=2,294,15 \cdot 7 \%)$ more often had $\geq 2$ exacerbations per year compared to patients without respiratory comorbidity $(8 \cdot 2 \%$ vs $5 \cdot 7 \%, p<0 \cdot 001)$.

Univariable logistic regression analysis showed that COPD patients with pulmonary cancer had 1.81 higher odds for $\geq 2$ exacerbations per year compared to patients without pulmonary cancer (Fig. 1, $p=0.002$ ). Patients who, next to their COPD, also suffered from asthma, blindness or low vision, coronary heart disease, depression, dyspepsia, heart failure, osteoporosis or osteopenia, peripheral vascular disease, or prostate disorders, had a higher risk of having frequent exacerbations compared to those who did not suffer from these comorbid conditions (Fig. 1).

Table 4 lists the comorbidities and comorbidity categories significantly associated with having $\geq 2$ exacerbation per year. In the multivariable logistic regression analysis, among the statistically significant associations, the highest ORs for having $\geq 2$ exacerbations per year were observed for pulmonary cancer (OR 1.85; 95\% CI 1.28-2.67), heart failure (OR 1 . $72 ; 1 \cdot 38-2 \cdot 14)$, prostate disorders (OR $1 \cdot 50 ; 1 \cdot 13-$ $1 \cdot 98$ ) and blindness/low vision (OR $1 \cdot 46 ; 1 \cdot 21-1 \cdot 75)$ as comorbid conditions (Table 4). Dislipidemia was not statistically significant, but did show a trend, with an OR of 0.81 (95\% CI $0.65-1 \cdot 01, p=0.071)$. When looking at comorbidity categories, patients 
Table 1 Baseline characteristics of the COPD study population grouped by low ( $<2 /$ year) versus high ( $\geq 2 /$ year) exacerbation rate

\begin{tabular}{|c|c|c|c|}
\hline \multirow[b]{2}{*}{ Patient characteristics } & \multirow{2}{*}{$\begin{array}{l}\text { Patients with full follow-up (study population) }{ }^{a} \\
(n=14,603)\end{array}$} & \multicolumn{2}{|l|}{ Subgroups of study population } \\
\hline & & $\begin{array}{l}\text { Patients with }<2 \text { exacerbations/year } \\
(n=13,709)\end{array}$ & $\begin{array}{l}\text { Patients with } \geq 2 \text { exacerbations/year } \\
(n=894)^{b}\end{array}$ \\
\hline Sex, male, n (\%) & $7,749(53 \cdot 1)$ & $7,322(53 \cdot 4)$ & $427(47 \cdot 8)^{\ddagger}$ \\
\hline $\begin{array}{l}\text { Age at study baseline, years; } \\
\text { mean (SD; range) }\end{array}$ & $66 \cdot 5(11 \cdot 5 ; 40-110)^{\ddagger}$ & $66 \cdot 5(11 \cdot 6 ; 40-110)$ & $67 \cdot 4(10 \cdot 3 ; 40-93)^{\ddagger}$ \\
\hline \multicolumn{4}{|c|}{ Full dataset available (censored data), n (\%) } \\
\hline Full data available & & $13,709(93 \cdot 9)$ & $894(6 \cdot 1)$ \\
\hline Deceased & N/A & N/A & $\mathrm{N} / \mathrm{A}$ \\
\hline Moved & N/A & N/A & N/A \\
\hline Nursing home & N/A & N/A & N/A \\
\hline Unknown & N/A & N/A & N/A \\
\hline \multicolumn{4}{|l|}{ Comorbidity data } \\
\hline $\begin{array}{l}\text { Number of comorbid } \\
\text { diseases', mean (SD; range) }\end{array}$ & $3 \cdot 0(2 \cdot 3 ; 0-20)^{\ddagger}$ & $3 \cdot 0(2 \cdot 3 ; 0-16)$ & $3 \cdot 4(2 \cdot 5 ; 0-20)^{\ddagger}$ \\
\hline \multicolumn{4}{|c|}{ Number of comorbid diseases categories ${ }^{c}, \mathrm{n}(\%)$} \\
\hline 0 & $1,777(12 \cdot 2)$ & $1,700(12 \cdot 4)$ & $77(8 \cdot 6)$ \\
\hline 1 or 2 & $5,305(36 \cdot 6)$ & $5,021(36 \cdot 6)$ & $284(31 \cdot 8)$ \\
\hline 3 or 4 & $4,258(29 \cdot 2)$ & $3,977(29 \cdot 0)$ & $281(31 \cdot 4)$ \\
\hline 5 and more & $3,263(22 \cdot 3)^{\ddagger}$ & $3,011(22 \cdot 0)$ & $252(28 \cdot 2)^{\ddagger}$ \\
\hline \multicolumn{4}{|l|}{ Exacerbations } \\
\hline $\begin{array}{l}\text { Number of exacerbations, } \\
\text { mean (SD; range) }\end{array}$ & $0 \cdot 75(1 \cdot 5 ; 0-15)^{\ddagger}$ & $0 \cdot 44(0 \cdot 8 ; 0-2)$ & $5 \cdot 6(2 \cdot 0 ; 3-15)^{\ddagger}$ \\
\hline \multicolumn{4}{|c|}{$\begin{array}{l}S D \text { standard deviation, N/A not applicable } \\
{ }^{*} p<0.05,{ }^{+} p<0.01,{ }^{\ddagger} p<0.001 \\
{ }^{p} p \text {-values displayed are calculated for the difference between patients lost to follow-up versus patients with full follow-up. Chi-square tests for categorized variables and } \\
\text { independent } t \text {-tests for continuous variables. } p<0 \cdot 05 \text { was considered statistically significant } \\
{ }^{b} p \text {-values displayed are calculated for the difference between the subgroups }<2 \text { versus } \geq 2 \text { exacerbations/year. Chi-square tests for categorized variables } \\
\text { and independent } t \text {-tests for continuous variables. } p<0 \cdot 05 \text { was considered statistically significant } \\
{ }^{c} \text { presence of any type of comorbid disease was assessed at study baseline, i.e., } 1 \text { January } 2012 \\
{ }^{d} \text { Mean number of exacerbations during the study period, } 1 \text { January } 2012-31 \text { December } 2013 \\
\text { Baseline characteristics of the initial population of all COPD patients }(n=16,427) \text { and those who were lost to follow-up ( } n=1,824) \text { are reported in Appendix } 3\end{array}$} \\
\hline
\end{tabular}

with other chronic respiratory conditions (OR 1.37; 1.15-1.64) and psychiatric comorbidities (OR 1.35; $1 \cdot 13-1 \cdot 60)$ were at highest risk for frequent exacerbations.

\section{Time to first exacerbation}

Table 5 summarizes the results from the Cox regression analyses. Among the statistically significant associations, the comorbid conditions with the highest risk of developing a first exacerbation were recurrent sinusitis (Cox hazard ratio $1 \cdot 53$; 95\% CI, $1 \cdot 05-2 \cdot 24)$, bronchiectasis/ chronic bronchitis $(\mathrm{HR}=1.50 ; 1.31-1.73)$ and heart failure $(1 \cdot 41 ; 1 \cdot 29-1 \cdot 55)$. For dislipidemia a nonstatistically HR of 0.92 was observed $(p=0.067,95 \%$ CI $0 \cdot 85-1 \cdot 00)$.

Having another chronic respiratory disease beside COPD was also associated with risk of developing a first exacerbation (Cox hazard ratio $1 \cdot 26 ; 1 \cdot 17-1 \cdot 36$ ), see Fig. 2.

\section{Discussion}

In this paper we explored the prevalence of comorbid chronic conditions and associations with exacerbation risk in a real-life cohort of primary care COPD patients. Our findings support the notion that comorbidities are rather rule than exception in patients with COPD [4], with $88 \%$ having at least one other chronic disease. Several comorbidities were associated with having frequent exacerbations, with heart failure, blindness/low vision and pulmonary cancer showing the strongest associations in terms of statistical significance. In contrast, diabetes was associated with a lower risk of having frequent exacerbations. Bronchiectasis/chronic bronchitis, heart failure and depression were the strongest predictors for developing a new exacerbation. 
Table 2 Prevalence of frequent and cardiopulmonary comorbidity in the study population, sorted from highest to lowest prevalence rate

\begin{tabular}{|c|c|c|c|c|}
\hline & $\begin{array}{l}\text { Total study population } \\
(n=14,603)\end{array}$ & $\begin{array}{l}\text { Patients with }<2 \text { exacerbations/year, } \\
(n=13,709)\end{array}$ & $\begin{array}{l}\text { Patients with } \geq 2 \text { exacerbations/year, } \\
(n=894)\end{array}$ & $p$-value ${ }^{b}$ \\
\hline \multicolumn{5}{|l|}{ Frequent comorbidity } \\
\hline Hypertension & $5,116(35 \cdot 0)$ & $4,805(35 \cdot 2)$ & $311(34 \cdot 8)$ & $0 \cdot 873$ \\
\hline Coronary heart disease & $2,759(18 \cdot 9)$ & $2,569(18 \cdot 7)$ & $191(21 \cdot 4)$ & $0 \cdot 051$ \\
\hline Osteoarthritis & $2,570(17 \cdot 6)$ & $2,402(17 \cdot 5)$ & $168(18 \cdot 8)$ & $0 \cdot 334$ \\
\hline Diabetes & $2,464(16 \cdot 9)$ & $2,33017 \cdot 0)$ & $134(15 \cdot 0)$ & $0 \cdot 120$ \\
\hline Peripheral vascular disease & 2,031 (13·9) & 1,897 (14·8) & $150(16 \cdot 8)$ & 0.006 \\
\hline Blindness \& low vision & $1,938(13 \cdot 3)$ & $1,772(12 \cdot 9)$ & $166(18 \cdot 6)$ & $<0.001$ \\
\hline Dyspepsia, gastroesophageal reflux & $1,845(12 \cdot 6)$ & $1,703(12 \cdot 4)$ & $142(15 \cdot 9)$ & 0.003 \\
\hline Dislipidemia & $1,703(11 \cdot 7)$ & $1,613(11 \cdot 8)$ & $90(10 \cdot 1)$ & $0 \cdot 125$ \\
\hline Stroke \& transient ischaemic attack & $1,357(9 \cdot 3)$ & $1,259(9 \cdot 2)$ & $98(11 \cdot 0)$ & $0 \cdot 076$ \\
\hline Chronic kidney diease & $1,360(9 \cdot 3)$ & $1,263(9 \cdot 2)$ & $97(10 \cdot 9)$ & $0 \cdot 103$ \\
\hline Asthma & $1,305(8 \cdot 9)$ & $1,202(8 \cdot 8)$ & $103(11 \cdot 5)$ & 0.005 \\
\hline Hearing loss & $1,144(7 \cdot 8)$ & $1,078(7 \cdot 9)$ & $66(7 \cdot 4)$ & $0 \cdot 604$ \\
\hline Heart failure & $1,048(7 \cdot 2)$ & $943(6 \cdot 9)$ & $105(11 \cdot 7)$ & $<0.001$ \\
\hline Atrial fibrillation & $1,044(7 \cdot 1)$ & $964(7 \cdot 0)$ & $80(8 \cdot 9)$ & $0 \cdot 031$ \\
\hline Skin cancer & $913(6 \cdot 3)$ & $862(6 \cdot 3)$ & $51(5 \cdot 7)$ & $0 \cdot 485$ \\
\hline Osteoporosis/osteopenia & $884(6 \cdot 1)$ & $801(5 \cdot 8)$ & $83(9 \cdot 3)$ & $<0.001$ \\
\hline Thyroid disorder & $808(5 \cdot 5)$ & $757(5 \cdot 5)$ & $51(5 \cdot 9)$ & $0 \cdot 817$ \\
\hline Depression & $800(5 \cdot 5)$ & $729(5 \cdot 3)$ & $71(7 \cdot 9)$ & 0.001 \\
\hline Prostate disorders & $784(5 \cdot 4)$ & $719(5 \cdot 2)$ & $65(7 \cdot 3)$ & 0.009 \\
\hline \multicolumn{5}{|l|}{ Cardiopulmonary comorbidity } \\
\hline Heart valve disease & $568(3 \cdot 9)$ & $528(3 \cdot 9)$ & $40(7 \cdot 8)$ & 0.035 \\
\hline Bronchiectasis/chronic bronchitis & $414(2 \cdot 8)$ & $379(2 \cdot 8)$ & $35(3 \cdot 9)$ & $0 \cdot 045$ \\
\hline Pulmonary cancer & $317(2 \cdot 2)$ & $284(2 \cdot 1)$ & $33(3 \cdot 7)$ & 0.001 \\
\hline Sleep apneu syndrome & $173(1 \cdot 2)$ & $161(1 \cdot 2)$ & $12(1 \cdot 3)$ & $0 \cdot 653$ \\
\hline Other chronic pulmonary disease & $157(1 \cdot 1)$ & $148(1 \cdot 1)$ & $9(1 \cdot 0)$ & $0 \cdot 838$ \\
\hline Recurrent sinusitis & $54(0 \cdot 4)$ & $49(0 \cdot 4)$ & $55(6 \cdot 2)$ & $0 \cdot 335$ \\
\hline Congenital cardiovascular anomaly & $32(0 \cdot 2)$ & $28(0 \cdot 2)$ & $4(0 \cdot 4)$ & $0 \cdot 132$ \\
\hline
\end{tabular}

${ }^{a}$ COPD population with complete data available, patients lost to follow-up ( $\left.n=1,824\right)$ excluded

${ }^{\mathrm{b}} p$-values displayed are calculated for the difference between the subgroup $<2$ versus $\geq 2$ exacerbations/year Chi-square tests for categorized variables. $p<0 \cdot 05$ was considered statistically significant

\section{Comparison with existing literature}

Previous research has shown that cardiovascular, psychiatric, and metabolic comorbidity are highly prevalent in COPD patients, $[8,17]$ and our results confirm these findings. In addition to the finding by Rutten et al. [18] that unrecognized heart failure is rather common in elderly patients with stable COPD, our data also indicate that heart failure may increase the risk of having frequent exacerbations. Recent clinical trial data have shown correlations between several comorbidities and mortality risk if a COPD patient is admitted to hospital with an acute exacerbation $[19,20]$. Our observations support the association between chronic comorbidity and exacerbation risk in a primary care study population, i.e., the COPD population without selection of any kind, which is unprecedented and impossible to derive from clinical trial populations [21].

We observed a trend towards statistical significance that COPD patients with dislipidemia had less frequent exacerbations compared to patients without dislipidemia (HR 0.92; $p=0.067$ ). This observation seems to be in line with findings by Ingebrigtsen et al., who recently reported that statin use for treatment of dislipidemia was associated with reduced odds of exacerbations in individuals with COPD [22] and findings by Chan et al. that 
Table 3 Prevalence of ICPC-categorized comorbidity in the COPD study population, sorted from highest to lowest prevalence rate of frequent exacerbations

\begin{tabular}{|c|c|c|c|c|}
\hline & $\begin{array}{l}\text { Study population } \\
(n=14,603)\end{array}$ & $\begin{array}{l}\text { Patients with }<2 \text { exacerbations/year, } \\
(n=13,709)\end{array}$ & $\begin{array}{l}\text { Patients with } \geq 2 \text { exacerbations/year } \\
(n=894)\end{array}$ & $p$-value ${ }^{b}$ \\
\hline \multicolumn{5}{|l|}{ Comorbidity category } \\
\hline Cardiovascular & $8,516(58 \cdot 3)$ & $7,955(58 \cdot 0)$ & $561(62 \cdot 8)$ & $0 \cdot 006$ \\
\hline Endocrine, metabolic and nutrition & $4,856(33 \cdot 3)$ & $4,568(33 \cdot 3)$ & $288(25 \cdot 5)$ & 0.496 \\
\hline Musculoskeletal & $3,588(24 \cdot 6)$ & $3,337(24 \cdot 3)$ & $251(28 \cdot 1)$ & $0 \cdot 012$ \\
\hline Eye and ear & $2,984(20 \cdot 4)$ & $2,762(20 \cdot 1)$ & $222(24 \cdot 8)$ & $0 \cdot 001$ \\
\hline Digestive & $2,801(19 \cdot 2)$ & $2,597(18 \cdot 9)$ & $204(22 \cdot 8)$ & $0 \cdot 004$ \\
\hline Urogenital (male and female) & $2,330(16 \cdot 0)$ & $2,146(15 \cdot 7)$ & $184(20 \cdot 6)$ & $<0 \cdot 001$ \\
\hline Psychiatric & $2,271(15 \cdot 6)$ & $2,092(15 \cdot 3)$ & $179(20 \cdot 0)$ & $<0 \cdot 001$ \\
\hline Non-pulmonary cancer & $2,203(15 \cdot 1)$ & $2,071(15 \cdot 1)$ & $132(14 \cdot 8)$ & $0 \cdot 782$ \\
\hline Respiratory (excl · pulmonary cancer) & $1,998(13 \cdot 7)$ & $1,839(13 \cdot 4)$ & $159(17 \cdot 8)$ & $<0 \cdot 001$ \\
\hline Skin & $1,395(9 \cdot 6)$ & $1,314(9 \cdot 6)$ & $81(9 \cdot 1)$ & $0 \cdot 605$ \\
\hline Neurological & $413(2 \cdot 8)$ & $389(2 \cdot 8)$ & $24(2 \cdot 7)$ & $0 \cdot 789$ \\
\hline Pulmonary cancer & $317(2 \cdot 2)$ & $284(2 \cdot 1)$ & $33(3 \cdot 7)$ & $0 \cdot 001$ \\
\hline Blood (forming organs) and lymphatics & $106(0 \cdot 7)$ & $97(0 \cdot 7)$ & $9(1 \cdot 0)$ & $0 \cdot 307$ \\
\hline Infectious & $87(0 \cdot 6)$ & $80(0 \cdot 6)$ & $7(0 \cdot 8)$ & 0.453 \\
\hline
\end{tabular}

ICPC International Classification of Primary Care

${ }^{\text {a } T o t a l ~ C O P D ~ p o p u l a t i o n, ~ w i t h ~ p a t i e n t s ~ w h o ~ w e r e ~ l o s t ~ t o ~ f o l l o w-u p ~}(n=1,824)$ excluded

${ }^{b} p$-values displayed are calculated for the difference between the group $<2$ versus $\geq 2$ exacerbations/year. We performed Chi-square tests for categorized variables. $p$-value $<0.05$ was considered statistically significant

hyperlipidemia in COPD was associated with decreased incidence of pneumonia and mortality in retrospective analyses of health insurance data [23]. Intuitively, the observed lower risk of frequent exacerbations in COPD patients with comorbid diabetes might be sought in GPs' reluctance to prescribe oral corticosteroids in these patients because the impact this may have on glucose levels, but a survey among Dutch GPs showed that most of them do not adjust treatment of exacerbations to the presence of diabetic comorbidity [24]. Gastroesophageal reflux disease $(\mathrm{OR}=1.25$ (95\% CI 1.03-1.50) in our analyses) was recognized as a significant predictor of acute exacerbations of COPD in a recent review by Lee et al [25]. A relationship between prostate disorders and exacerbations has not been described in the literature, but might be related to use of inhaled anticholinergics.

\section{Strengths and limitations}

A strength of this study is the inclusion of $>14$ thousand COPD patients from a real-life, unbiased primary care setting. However, the main strength is not so much the uniqueness or even the size of our dataset. Other existing general practice databases essentially contain the same, or even more detailed data regarding diagnoses and medication prescriptions, [26-29] but the meticulousness with which we have looked at ALL chronic comorbidity, including recurrent episodes of conditions that are not necessarily chronic in all patients, seems unprecedented. Moreover, other existing databases with real-life general practice COPD data mainly stem from the UK and Denmark, and now there is also one available from the Netherlands. We intentionally applied minimal exclusion criteria in order to maximize generalizability of the results. Another strength is the wide range of chronic comorbidities investigated, summing up to a total of 82 conditions. Apart from all commonly known chronic comorbid diseases, we also included several recurrent diseases (i.e., depression, anxiety, anemia, dyspepsia, urinary tract infection) and applied criteria to define their chronicity based on disease specific guidelines (see Appendix 1). Inclusion of patients with recurrent diseases seems relevant when studying risk factors for COPD exacerbations, but has not been done in previous studies.

Our study was based on patients' medical records in general practice. Limited agreement between medical record-based and objectively identified comorbidities of COPD [30] and undiagnosed comorbidity in COPD patients is common $[18,31]$. This may have resulted in underestimation of the presence of comorbidity in our 

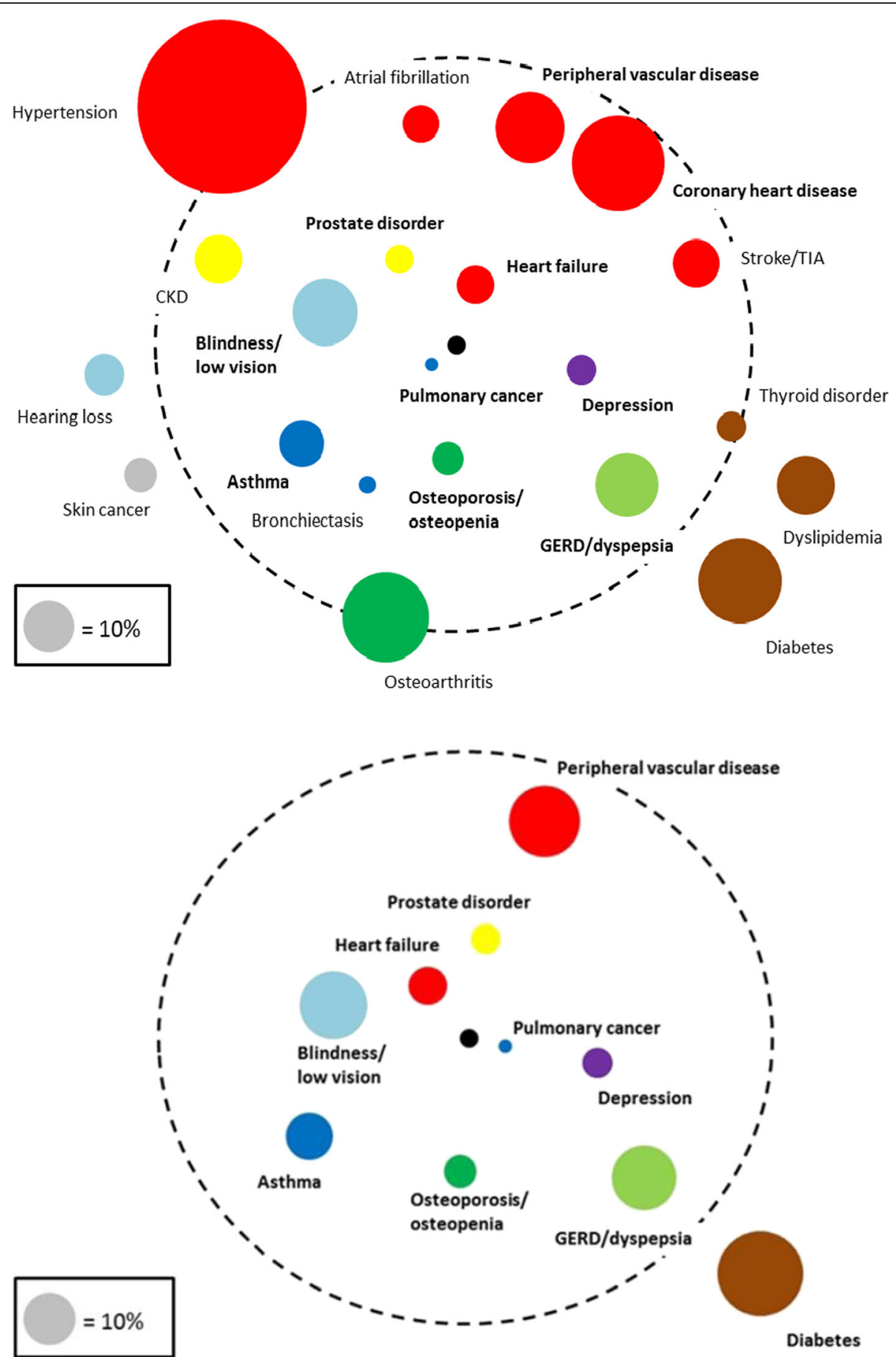

Fig. 1 Comorbidome of comorbidities in the COPD study population $(n=14,603)$. Results are from univariable (upper panel) and multivariable (lower panel, corrected for age, gender and the other comorbidities) logistic regression analysis. (Diameter of the coloured circles represents the prevalence of each comorbidity. Proximity to the black centre of the circle represents stronger positive association (OR) with $\geq 2$ exacerbation per year. The dashed circle represents an OR of 1. Comorbidities marked bold were statistically significantly (i.e., $p<0.05$ ) associated with increased or decreased risk. In the multivariable model covariates were sequentially dropped until only statistically significant covariates remained.

Comorbidities outside the dashed circle were negatively associated (i.e., 'protective') with $\geq 2$ exacerbation/year. Comorbidities with prevalence $<5 \%$ were not analysed). CKD: chronic kidney disease. COPD: chronic obstructive pulmonary disease. GERD: gastroesophageal reflux disease. TIA: transient ischemic attack 
Table 4 Comorbidities associated with $\geq 2$ exacerbations/year versus $<2$ exacerbations/year in COPD patients, corrected for age and sex (multivariable results), sorted by $p$-value

\begin{tabular}{|c|c|c|}
\hline & Odds ratio $(95 \% \mathrm{Cl})$ & $p$-value \\
\hline \multicolumn{3}{|l|}{ Comorbid conditions, $\mathrm{a}$} \\
\hline Heart failure & $1 \cdot 72(1 \cdot 38-2 \cdot 14)$ & $<0 \cdot 001$ \\
\hline Blindness \& low vision & $1 \cdot 46(1 \cdot 21-1 \cdot 75)$ & $<0 \cdot 001$ \\
\hline Pulmonary cancer & $1 \cdot 85(1 \cdot 28-2 \cdot 67)$ & $0 \cdot 002$ \\
\hline Depression & $1 \cdot 48(1 \cdot 14-1 \cdot 91)$ & $0 \cdot 003$ \\
\hline Prostate disorders & $1 \cdot 50(1 \cdot 13-1 \cdot 98)$ & $0 \cdot 004$ \\
\hline Asthma & $1 \cdot 36(1 \cdot 11-1 \cdot 70)$ & $0 \cdot 004$ \\
\hline Osteoporosis/osteopenia & $1 \cdot 41(1 \cdot 11-1 \cdot 80)$ & $0 \cdot 006$ \\
\hline Diabetes & $0 \cdot 80(0 \cdot 66-0 \cdot 97)$ & $0 \cdot 020$ \\
\hline Dyspepsia, gastroesophageal reflux & $1 \cdot 25(1 \cdot 03-1 \cdot 50)$ & $0 \cdot 023$ \\
\hline Peripheral vascular disease & $1 \cdot 20(1 \cdot 00-1 \cdot 45)$ & $0 \cdot 049$ \\
\hline \multicolumn{3}{|l|}{ Comorbidity categories, $\mathrm{b}_{\mathrm{c}}$} \\
\hline Respiratory (excl. pulmonary cancer) & $1 \cdot 37(1 \cdot 15-1 \cdot 64)$ & $<0 \cdot 001$ \\
\hline Psychiatric & $1 \cdot 35(1 \cdot 13-1 \cdot 60)$ & $<0 \cdot 001$ \\
\hline Urogenital (male and female) & $1 \cdot 34(1 \cdot 12-1 \cdot 60)$ & $<0 \cdot 001$ \\
\hline Eye and ear & $1 \cdot 25(1 \cdot 06-1 \cdot 47)$ & $0 \cdot 007$ \\
\hline Endocrine, metabolic and feeding & $0 \cdot 85(0 \cdot 73-0 \cdot 99)$ & $0 \cdot 032$ \\
\hline Cardiovascular & $1 \cdot 17(1 \cdot 01-1 \cdot 36)$ & $0 \cdot 037$ \\
\hline
\end{tabular}

OR odds ratio

${ }^{a}$ All chronic comorbidities with prevalence $\geq 5 \%$ and cardiopulmonary comorbidities were included in the multivariable logistic regression model beference category was 'comorbidity not diagnosed before study period' (i.e., 1 January 2012)

'All ICPC comorbidity categories were included in the multivariate logistic regression mode

study population. The use of real-life data presents limitations, for instance the fact that patients' smoking history and lung function could not be included because this information is not consistently and uniformly documented in general practice medical records. We chose to limit the analyses to comorbidities with a relatively high (i.e., $\geq 5 \%$ ) prevalence. This may mean that comorbidities that are related to increased exacerbation risk but have a low prevalence rate in the COPD patient population were missed.

We defined an exacerbation as an oral corticosteroid prescription, which is the recommended treatment for acute exacerbations in Dutch COPD guidelines [15]. Consequently, mild exacerbations treated with bronchodilators only are not included in our analyses. Oral steroid prescriptions during GP out-of-office hours, emergency department visits and hospitalizations, and prescriptions by pulmonary specialists may not always have been included for all patients, as these are not automatically added to patients' medical records in all electronic patient record systems. Because there is no
Table 5 Comorbidities associated with development of a first exacerbation in the study population, corrected for age and sex (results from multivariable Cox regression analysis), sorted by $p$-value

Cox hazard ratio $(95 \% \mathrm{Cl}) \quad p$-value

Comorbidity $^{\mathrm{a}, \mathrm{b}}$

\begin{tabular}{|c|c|c|}
\hline Bronchiectasis/chronic bronchitis & $1 \cdot 50(1 \cdot 31-1 \cdot 73)$ & $<0 \cdot 001$ \\
\hline Heart failure & $1 \cdot 41(1 \cdot 29-1 \cdot 55)$ & $<0 \cdot 001$ \\
\hline Depression & $1 \cdot 34(1 \cdot 20-1 \cdot 50)$ & $<0 \cdot 001$ \\
\hline Atrial fibrillation & $1 \cdot 27(1 \cdot 16-1 \cdot 40)$ & $<0 \cdot 001$ \\
\hline Asthma & $1 \cdot 24(1 \cdot 14-1 \cdot 36)$ & $<0 \cdot 001$ \\
\hline Peripheral vascular disease & $1 \cdot 15(1 \cdot 07-1 \cdot 24)$ & $<0 \cdot 001$ \\
\hline Prostate disorders & $1 \cdot 20(1 \cdot 04-1 \cdot 45)$ & $0 \cdot 002$ \\
\hline Blindness \& low vision & $1 \cdot 11(1 \cdot 03-1 \cdot 20)$ & $0 \cdot 009$ \\
\hline Coronary heart disease & $1 \cdot 10(1 \cdot 02-1 \cdot 17)$ & $0 \cdot 011$ \\
\hline $\begin{array}{l}\text { Dyspepsia, gastroesophageal } \\
\text { reflux }\end{array}$ & $1 \cdot 10(1 \cdot 02-1 \cdot 20)$ & $0 \cdot 013$ \\
\hline Pulmonary cancer & $1 \cdot 23(1 \cdot 04-1 \cdot 45)$ & $0 \cdot 016$ \\
\hline Recurrent sinusitis & $1 \cdot 53(1 \cdot 05-2 \cdot 24)$ & $0 \cdot 028$ \\
\hline Osteoporosis/osteopenia & $1 \cdot 12(1 \cdot 01-1 \cdot 25)$ & $0 \cdot 037$ \\
\hline \multicolumn{3}{|l|}{ Lomorbidity category ${ }^{b, c}$} \\
\hline $\begin{array}{l}\text { Respiratory (excl. pulmonary } \\
\text { cancer) }\end{array}$ & $1 \cdot 26(1 \cdot 17-1 \cdot 36)$ & $<0 \cdot 001$ \\
\hline Urogenital (male and female) & $1 \cdot 18(1 \cdot 10-1 \cdot 27)$ & $<0 \cdot 001$ \\
\hline Cardiovascular & $1 \cdot 16(1 \cdot 08-1 \cdot 24)$ & $<0 \cdot 001$ \\
\hline Mental health & $1 \cdot 16(1 \cdot 08-1 \cdot 24)$ & $<0 \cdot 001$ \\
\hline Eye and ear & $1 \cdot 09(1 \cdot 02-1 \cdot 16)$ & 0.013 \\
\hline Digestive & $1 \cdot 07(1 \cdot 00-1 \cdot 15)$ & $0 \cdot 042$ \\
\hline
\end{tabular}

${ }^{a}$ All chronic comorbidities with prevalence $\geq 5 \%$ and cardiopulmonary comorbidities were included in the multivariate Cox regression model ${ }^{\text {b}}$ Reference category was 'comorbidity not diagnosed before study period' (i.e., 1 January, 2012)

'All ICPC comorbidity categories were included in the multivariate Cox regression model

international consensus about a definition that discriminates relapse of an earlier exacerbation from a new one, our (arbitrary) choice to use an interval of $\geq 14$ days since the end date of the previous oral steroid prescription may have led to under- or overestimation of the number of exacerbations. Unfortunately, the rather crude prescription information did not allow us to look at the impact of comorbidities on the duration or progression of exacerbations. Although observational studies such as ours lack the rigorous internal validity that is typical for randomized controlled trials, they provide valuable insight into comorbidity prevalence in COPD and its relation with an important outcome, i.e., exacerbations. As such, our findings should be considered in conjunction with those arising from other study designs, including randomized trials. 


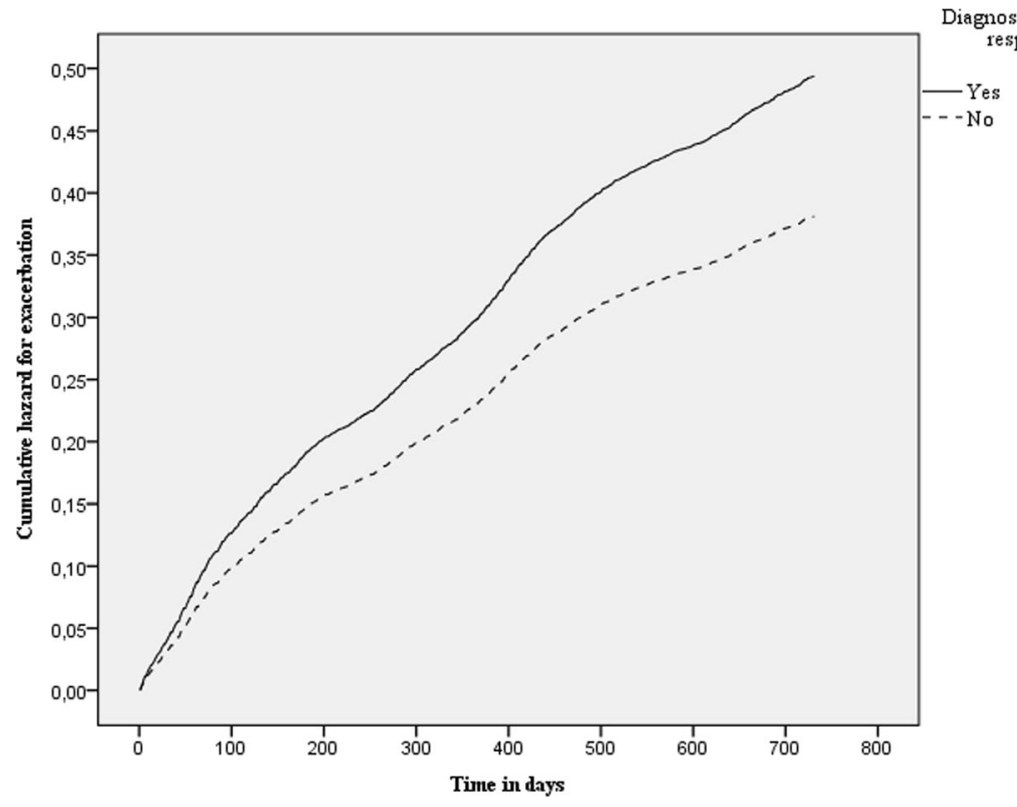

Fig. 2 Hazard for exacerbation split by COPD patients with versus without one or more diagnoses of other chronic respiratory diseases at baseline. (Patients with another chronic respiratory disease next to their COPD showed a higher hazard rate for the development of a first exacerbation (Cox hazard ratio 1.26; 1.17-1.36) compared to patients without another chronic respiratory disease). COPD: chronic obstructive pulmonary disease

\section{Clinical implications}

Better knowledge about the role that comorbidity plays in COPD exacerbation risk may contribute to lower exacerbation rates in COPD patients through patienttailored and systems medicine approaches. In turn, reduction of exacerbations may improve patients' quality of life and prevent disability, hospitalizations, and mortality. A challenge for researchers is to find ways to enable physicians to take comorbidity into account when assessing COPD patients' exacerbation risk. Putcha et al. developed a simple score that includes 14 comorbidities, where one point increase in comorbidity count was associated with $21 \%$ higher exacerbation risk [9]. However, their comorbidity score does not include comorbidities such as asthma, lung cancer and depression, while our results indicate that these comorbidities are also related to exacerbation risk. Neither does Putcha's score take differences in exacerbation risk for different comorbidities into account. This highlights the importance of including a wide range of comorbid chronic conditions like we did in our study.

Beside Putcha's comorbidity score, several prognostic indices to support COPD patient care have been developed, [32] most of them predicting prognosis in terms of mortality or hospitalization. Only few indices predict exacerbation risk and only one (the DOSE index [33]) has been developed and validated in primary care [34].
Comorbidity is not included in the existing prognostic indices, with the exception of the COTE index, which assesses mortality and not exacerbation risk [10, 11]. Our results may contribute to the development of a prognostic index that connects comorbidities with exacerbation risk to identify patients at highest risk, thereby potentially reducing disease progression.

\section{Conclusion}

We have confirmed that many patients with COPD are affected by chronic comorbidities. Several highly prevalent as well as cardiopulmonary comorbidities appear to be independently associated with the risk of suffering from frequent exacerbations in our unbiased primary care patient population. Apart from clinical COPD guidelines advising that comorbidities should be diagnosed and treated appropriately, insight in patients' comorbidity patterns could also be used to identify those that are more likely to suffer from frequent exacerbations. Further research is needed to assess opportunities of implementation of this knowledge in routine care, so that patient-centered COPD care that also takes comorbidity into account can become the standard. Ultimately this may contribute to reducing disease progression and reduce the significant burden that COPD and its exacerbations puts on patients and healthcare systems. 


\section{Appendix 1}

Table 6 List of 82 comorbidities included in comorbidity selection, sorted by prevalence (\%) in the study population

\begin{tabular}{|c|c|c|c|c|}
\hline Comorbiditiy & Prevalence (\%) & Diagnosis & ICPC code & Inclusion criteria \\
\hline Hypertension & 35.2 & Hypertension & K86, K87 & ICPC code before 1-1-12 \\
\hline \multirow[t]{2}{*}{ Coronary heart disease } & 19.2 & $\begin{array}{l}\text { Myocardial infarction/other } \\
\text { ischemic heart disease }\end{array}$ & $\begin{array}{l}\text { K75, K76, K76.02, } \\
\text { K76.01 }\end{array}$ & ICPC code before 1-1-12 \\
\hline & & Angina Pectoris & K74, K74.01, K74.02 & ICPC code before 1-1-12 \\
\hline \multirow[t]{4}{*}{ Osteoarthritis } & 17.6 & $\begin{array}{l}\text { Artrose/spondylose } \\
\text { wervelkolom }\end{array}$ & L84, L84.01, L84.02 & ICPC code before 1-1-12 \\
\hline & & Gonartrose & L90 & ICPC code before 1-1-12 \\
\hline & & Coxartrose & L89 & ICPC code before 1-1-12 \\
\hline & & Osteoarhritis, other & L91 & ICPC code before 1-1-12 \\
\hline Diabetes & 17.3 & $\mathrm{DM} 1, \mathrm{DM} 2$ & T90, T90.01, T90.02 & ICPC code before 1-1-12 \\
\hline \multirow[t]{3}{*}{ Peripheral vascular disease } & 14.3 & Atherosclerose & K91 & ICPC code before 1-1-12 \\
\hline & & $\begin{array}{l}\text { Intermittent claudication/ } \\
\text { Raynaud/Buerger }\end{array}$ & $\begin{array}{l}\text { K92, K92.01, K92.02, } \\
\text { K92.03 }\end{array}$ & ICPC code before 1-1-12 \\
\hline & & $\begin{array}{l}\text { Other disease cardiovascular } \\
\text { system }\end{array}$ & $\begin{array}{l}\text { K99, K99.01, K99.02, K } \\
99.03, \text { K99.04, K99.05, } \\
\text { K99.06 }\end{array}$ & ICPC code before 1-1-12 \\
\hline \multirow[t]{4}{*}{ Blindness \& low vision } & 13.8 & $\begin{array}{l}\text { (Diabetic/hypertensive) } \\
\text { retinopathy }\end{array}$ & F83, F83.01, F83.02 & ICPC code before 1-1-12 \\
\hline & & Maculadegeneratie & F84 & ICPC code before 1-1-12 \\
\hline & & Blindness/amblyopia & F94 & ICPC code before 1-1-12 \\
\hline & & Cataract & F92, F92.01 & ICPC code before 1-1-12 \\
\hline \multirow[t]{4}{*}{$\begin{array}{l}\text { Dyspepsia, Gastroesophageal } \\
\text { reflux (GERD) }\end{array}$} & 12.6 & Stomach ulcer & D86.01 & $\begin{array}{l}\text { ICPC code before 1-1-12 AND (recode } \\
\text { OR connection to episode) } 12 \text { months } \\
\text { after first ICPC [35] }\end{array}$ \\
\hline & & Duodenal ulcer & D85 & $\begin{array}{l}\text { ICPC code before 1-1-12 AND (recode } \\
\text { OR connection to episode) } 12 \text { months } \\
\text { after first ICPC [35] }\end{array}$ \\
\hline & & Peptic ulcer, other & D86 & $\begin{array}{l}\text { ICPC code before 1-1-12 AND (recode } \\
\text { OR connection to episode) } 12 \text { months } \\
\text { after first ICPC [35] }\end{array}$ \\
\hline & & $\begin{array}{l}\text { Oesophagus reflux with } \\
\text { and without oesophagitis }\end{array}$ & $\begin{array}{l}\text { D87, D87.01, D87.02, } \\
\text { D84, D84.02, D84.03 }\end{array}$ & $\begin{array}{l}\text { ICPC code before 1-1-12 AND (recode } \\
\text { OR connection to episode) } 12 \text { months } \\
\text { after first ICPC [35] }\end{array}$ \\
\hline Dislipidemia & 11.5 & $\begin{array}{l}\text { Hypercholesterolemia/ } \\
\text { hypertriglyceridemia }\end{array}$ & $\begin{array}{l}\text { T93, T93.01, T93.02, } \\
\text { T93.03, T93.04 }\end{array}$ & ICPC code before 1-1-12 \\
\hline \multirow[t]{2}{*}{$\begin{array}{l}\text { Stroke \& transient ischaemic } \\
\text { attack }\end{array}$} & 9.7 & $\begin{array}{l}\text { TIA (transient ischemic } \\
\text { accident) }\end{array}$ & K89 & ICPC code before 1-1-12 \\
\hline & & CVA (cerebrovascular accident) & $\begin{array}{l}\text { K90, K90.01, K90.02, } \\
\text { K90.03 }\end{array}$ & ICPC code before 1-1-12 \\
\hline Chronic kidney diease & 9.5 & Renal dysfunction & U99, U99.01 & ICPC code before 1-1-12 \\
\hline Asthma & 8.5 & Asthma & R96, R96.01, R96.02 & $\begin{array}{l}\text { ICPC code before 1-1-2012 AND (recode } \\
\text { OR connection to episode) } 24 \text { months } \\
\text { after first ICPC code [36] }\end{array}$ \\
\hline \multirow[t]{2}{*}{ Hearing loss } & 8.1 & Deafness & $\mathrm{H} 84, \mathrm{H} 86, \mathrm{H} 85$ & ICPC code before 1-1-12 \\
\hline & & Otosclerosis & $\mathrm{H} 83$ & ICPC code before 1-1-12 \\
\hline \multirow[t]{2}{*}{ Heart failure } & 7.9 & (congestive) heart failure & K77, K77.01, K77.02 & ICPC code before 1-1-12 \\
\hline & & Pulmonary heart disease & K82 & ICPC code before 1-1-12 \\
\hline Atrial fibrillation & 7.5 & Atrial fibrillation/flutter & K78 & ICPC code before 1-1-12 \\
\hline Skin cancer & 6.3 & Skin cancer & & ICPC code before 1-1-12 \\
\hline
\end{tabular}


Table 6 List of 82 comorbidities included in comorbidity selection, sorted by prevalence (\%) in the study population (Continued)

\begin{tabular}{|c|c|c|c|c|}
\hline & & & $\begin{array}{l}\text { S77.01, S77.02, } \\
\text { S77.03, S77.04, S77 }\end{array}$ & \\
\hline Osteoporosis/osteopenia & 6.3 & Osteoporosis/osteopenie & L95, L95.01, L95.02 & ICPC code before 1-1-12 \\
\hline Depression & 5.6 & Depressive disorder & P76, P76.01 & $\begin{array}{l}\text { ICPC code before 1-1-2012 AND (recode } \\
\text { OR connection to episode) } 24 \text { months } \\
\text { after first ICPC code }[37,38]\end{array}$ \\
\hline \multirow[t]{2}{*}{ Thyroid disorder } & 5.6 & Hypothyroidism & T86 & ICPC code before 1-1-12 \\
\hline & & Hyperthyroidism & T85 & ICPC code before 1-1-12 \\
\hline Psoariasis & 4.6 & Psoriasis & 591 & ICPC code before 1-1-12 \\
\hline Obesity & 4.4 & Adipositas & T82 & ICPC code before 1-1-12 \\
\hline \multirow[t]{6}{*}{ Anxiety } & 4.3 & Somatoform disorder & P75 & $\begin{array}{l}\text { ICPC code before 1-1-2012 AND (recode } \\
\text { OR connection to episode) } 24 \text { months } \\
\text { after first ICPC code [39] }\end{array}$ \\
\hline & & Phobia & P79.01 & $\begin{array}{l}\text { ICPC code before 1-1-2012 AND (recode } \\
\text { OR connection to episode) } 24 \text { months } \\
\text { after first ICPC code [39] }\end{array}$ \\
\hline & & Anxiety disorder & P74, P 74.01, P74.02 & $\begin{array}{l}\text { ICPC code before 1-1-2012 AND (recode } \\
\text { OR connection to episode) } 24 \text { months } \\
\text { after first ICPC code [39] }\end{array}$ \\
\hline & & $\begin{array}{l}\text { Obsessive - compulsive } \\
\text { disorder }\end{array}$ & P79.02 & $\begin{array}{l}\text { ICPC code before 1-1-2012 AND (recode } \\
\text { OR connection to episode) } 24 \text { months } \\
\text { after first ICPC code [39] }\end{array}$ \\
\hline & & $\begin{array}{l}\text { (chronic) functional somatic } \\
\text { symtoms }\end{array}$ & P01, P78 & $\begin{array}{l}\text { ICPC code before 1-1-2012 AND (recode } \\
\text { OR connection to episode) } 24 \text { months } \\
\text { after first ICPC code [39] }\end{array}$ \\
\hline & & Post traumatic stress disorder & P02.01 & $\begin{array}{l}\text { ICPC code before 1-1-2012 AND (recode } \\
\text { OR connection to episode) } 24 \text { months } \\
\text { after first ICPC code [39] }\end{array}$ \\
\hline Eczema & 4.1 & Atopic dermatitis & S87 & ICPC code before 1-1-12 \\
\hline \multirow[t]{2}{*}{ Heart valve disease } & 3.9 & Heart valve disease & K83, K83.01, K83.02 & ICPC code before 1-1-12 \\
\hline & & Heart valve disease (rheumatic) & K71.02 & ICPC code before 1-1-12 \\
\hline $\begin{array}{l}\text { Diverticular disease of } \\
\text { intestine }\end{array}$ & 3.9 & Colonic diverticula, diverticulitis & D92 & ICPC code before 1-1-12 \\
\hline Alcohol problems & 3.9 & Chronic alcohol abuse & $\begin{array}{l}\text { P15, P15.01, P15.02, } \\
\text { P15.03, P15.04, } \\
\text { P15.05, P15.06 }\end{array}$ & ICPC code before 1-1-12 \\
\hline $\begin{array}{l}\text { Rheumatoid arthritis, other } \\
\text { inflammatory polyarthropathies } \\
\text { \& systemic connective tissue } \\
\text { disorders }\end{array}$ & 3.7 & $\begin{array}{l}\text { Rheumatoid arthritis/ } \\
\text { ankylosing spondylarthritis }\end{array}$ & L88.01, L88.02, L88 & ICPC code before 1-1-12 \\
\hline Bronchiectasis/chronic bronchitis & 2.8 & $\begin{array}{l}\text { Bronchiectasis/Chronic } \\
\text { bronchitis }\end{array}$ & R91.02, R91, R91.01 & ICPC code before 1-1-12 \\
\hline Irritable bowel syndrome & 2.8 & Irritable bowel syndrom & D93 & ICPC code before 1-1-12 \\
\hline \multirow[t]{2}{*}{ Venous insufficiency } & 2.4 & Venous insufficiency & K99.04 & ICPC code before 1-1-12 \\
\hline & & Varicose ulcer & S97, S97.01 & $\begin{array}{l}\text { ICPC code AND (recode OR connection } \\
\text { to episode) } 3 \text { months after first } \\
\text { ICPC code }[40]\end{array}$ \\
\hline Pulmonary cancer & 2.4 & lung/bronchial cancer & R84 & ICPC code before 1-1-12 \\
\hline Recurrent urinary tract infection & 2.3 & $\begin{array}{l}\text { Urinary tract infection, } \\
\text { chronic/recurrent }\end{array}$ & U71, U71.01, U71.02 & $\begin{array}{l}\text { ICPC code AND (recode OR connection } \\
\text { to episode) } \geq 3 \text { times/year in 2011, 2012, } \\
\text { 2013. Years start with 1e ICPC code. } \\
\text { Minimal } 8 \text { weeks between each } \\
\text { episode [41] }\end{array}$ \\
\hline Breast cancer & 2.3 & Breat cancer & $X 76, X 76.01$ & ICPC code before 1-1-12 \\
\hline
\end{tabular}


Table 6 List of 82 comorbidities included in comorbidity selection, sorted by prevalence (\%) in the study population (Continued)

\begin{tabular}{|c|c|c|c|c|}
\hline Glaucoma & 2.2 & $\begin{array}{l}\text { Glaucoma/verhoogde } \\
\text { oogboldruk }\end{array}$ & $\begin{array}{l}\text { F93, F93.01, F93.02, } \\
\text { F93.03, F93.04 }\end{array}$ & ICPC code before 1-1-12 \\
\hline Gout & 2.0 & Gout & T92 & $\begin{array}{l}\text { ICPC code AND (recode OR connection } \\
\text { to episode) } \geq 3 \text { times/year in 2011, 2012, } \\
\text { 2013. Years start with 1e ICPC code. } \\
\text { Minimal } 22 \text { days between each } \\
\text { episode [42] }\end{array}$ \\
\hline Prostate cancer & 1.9 & Prostate cancer & Y77 & ICPC code before 1-1-12 \\
\hline Dementia & 1.7 & $\begin{array}{l}\text { Alzheimer's disease/Senil } \\
\text { dementia/Alzheimer/Multi- } \\
\text { infarct dementia }\end{array}$ & P70.01, P70, P70.02 & ICPC code before 1-1-12 \\
\hline \multirow[t]{2}{*}{ Colorectal cancer } & \multirow[t]{2}{*}{1.7} & Colon cancer & D75 & ICPC code before 1-1-12 \\
\hline & & Rectal cancer & D75 & ICPC code before 1-1-12 \\
\hline Epilepsy & 1.4 & Epilepsy & N88 & ICPC code before 1-1-12 \\
\hline Bladder cancer & 1.3 & Bladder cancer & U76 & ICPC code before 1-1-12 \\
\hline Sleep apnea syndrome & 1.2 & Sleep apnea syndrome & P0601 & ICPC code before 1-1-12 \\
\hline $\begin{array}{l}\text { Underfeeding/vitamine } \\
\text { deficiency }\end{array}$ & 1.2 & $\begin{array}{l}\text { Underfeeding/vitamine } \\
\text { deficiency }\end{array}$ & T91, T05 & $\begin{array}{l}\text { ICPC code before 1-1-12 AND (recode } \\
\text { OR connection to episode) } 12 \text { months } \\
\text { after first ICPC }\end{array}$ \\
\hline Inflammatory bowel disease & 1.2 & $\begin{array}{l}\text { Crohn's disease/Ulcerative } \\
\text { colitis }\end{array}$ & D94, D94.01, D94.02 & ICPC code before 1-1-12 \\
\hline Personality disorder & 1.2 & Personality disorder & P80, P80.01, P80.02 & ICPC code before 1-1-12 \\
\hline Prostate disorders & 1.2 & $\begin{array}{l}\text { Prostatic hyperplasia/ } \\
\text { hypertrophy }\end{array}$ & Y85 & ICPC code before 1-1-12 \\
\hline \multirow[t]{3}{*}{ Other chronic pulmonary disease } & \multirow[t]{3}{*}{1.1} & Pulmonary tuberculosis & R70 & ICPC code before 1-1-12 \\
\hline & & Pneumoconiosis & R99.06 & ICPC code before 1-1-12 \\
\hline & & Sarcoidosis & R83.02 & ICPC code before 1-1-12 \\
\hline Chronic liver disease & 1 & Cirrose/steatose & D97, D97.04, D97.05 & ICPC code before 1-1-12 \\
\hline Genitourinary cancer, other & 0.9 & Genitourinary cancer, other & $\begin{array}{l}\text { U75, U77, X77, Y78, } \\
\text { Y78.01, Y78.03 }\end{array}$ & ICPC code before 1-1-12 \\
\hline \multirow[t]{4}{*}{$\begin{array}{l}\text { Blood(forming organs) and } \\
\text { lymphatics disorder }\end{array}$} & \multirow[t]{4}{*}{0.8} & $\begin{array}{l}\text { Benign non specified neoplasm } \\
\text { blood/lymphatic disorder }\end{array}$ & B75 & $\begin{array}{l}\text { ICPC code before 1-1-12 AND (recode } \\
\text { OR connection to episode) } 12 \text { months } \\
\text { after first ICPC [43] }\end{array}$ \\
\hline & & Haemophilia & B83.01 & ICPC code before 1-1-12 \\
\hline & & $\begin{array}{l}\text { Congenital blood/lymphatic } \\
\text { disorder }\end{array}$ & B79 & ICPC code before 1-1-12 \\
\hline & & $\begin{array}{l}\text { Purpura/coagulation disorders/ } \\
\text { abnormal trombocytes }\end{array}$ & B83, B83.02, B83.06 & ICPC code before 1-1-12 \\
\hline \multirow{3}{*}{$\begin{array}{l}\text { Schrizophrenia/non-organic } \\
\text { psychosis/bipolar disorder }\end{array}$} & \multirow[t]{3}{*}{0.8} & Schizophrenia & P72 & ICPC code before 1-1-12 \\
\hline & & Psychosis non specified & P98 & ICPC code before 1-1-12 \\
\hline & & Bipolar & P73.02 & ICPC code before 1-1-12 \\
\hline Migraine & 0.8 & Migraine & N89 & $\begin{array}{l}\text { ICPC code before 1-1-12 AND (recode } \\
\text { OR connection to episode) } 12 \text { months } \\
\text { after first ICPC [44] }\end{array}$ \\
\hline \multirow{3}{*}{$\begin{array}{l}\text { Cancer oropharynx, oesophageal, } \\
\text { stomach }\end{array}$} & \multirow[t]{3}{*}{0.8} & Cancer of the mouth/pharynx & D77.02, D77.03 & ICPC code before 1-1-12 \\
\hline & & Oesophageal cancer & D77.01, D77 & ICPC code before 1-1-12 \\
\hline & & Cancer of stomach & D74 & ICPC code before 1-1-12 \\
\hline $\begin{array}{l}\text { Other psychoactive substance } \\
\text { misuse }\end{array}$ & 0.7 & Substance abuse & P19, P19.01, P19.02 & ICPC code before 1-1-12 \\
\hline Parkinson's disease & 0.6 & Parkinson's disease & N87.01, N87 & ICPC code before 1-1-12 \\
\hline
\end{tabular}


Table 6 List of 82 comorbidities included in comorbidity selection, sorted by prevalence (\%) in the study population (Continued)

\begin{tabular}{|c|c|c|c|c|}
\hline \multirow[t]{2}{*}{$\begin{array}{l}\text { Other chronic skin disease/ } \\
\text { neoplasm (sub)cutis }\end{array}$} & \multirow[t]{2}{*}{0.6} & $\begin{array}{l}\text { Neoplasm cutis, subcutis } \\
\text { non specified }\end{array}$ & $\begin{array}{l}\text { S80, S80.01, S81, S83, } \\
\text { S83.01, S83.02 }\end{array}$ & ICPC code before 1-1-12 \\
\hline & & Vitiligo/lichen planus & S99.04, S99.06 & ICPC code before 1-1-12 \\
\hline \multirow[t]{3}{*}{ Viral hepatitis } & \multirow[t]{3}{*}{0.6} & Hepatitis B & D72.02, D72.04 & ICPC code before 1-1-12 \\
\hline & & Hepatitis C & D72.03, D72.05 & ICPC code before 1-1-12 \\
\hline & & Hepatitis & D72 & ICPC code before 1-1-12 \\
\hline Uterine cervical cancer & 0.5 & Uterine cervical cancer & $X 75$ & ICPC code before 1-1-12 \\
\hline \multirow{2}{*}{$\begin{array}{l}\text { Learning disability'/Mental } \\
\text { retardation }\end{array}$} & \multirow[t]{2}{*}{0.4} & Mental retardation & P85 & ICPC code before 1-1-12 \\
\hline & & Specified learning problems & $\begin{array}{l}\text { P24. P24.01, P24.02, } \\
\text { P24.03 }\end{array}$ & ICPC code before 1-1-12 \\
\hline Laryngeal/throat cancer & 0.4 & Laryngeal/troat cancer & R85 & ICPC code before 1-1-12 \\
\hline Hodgkin disease & 0.4 & Hodgkin disease & $\mathrm{B} 72, \mathrm{~B} 72.01, \mathrm{~B} 72.02$ & ICPC code before 1-1-12 \\
\hline Carcinoma, other & 0.4 & Carcinoma, other & $\begin{array}{l}\text { D77.04, T71, W72, } \\
\text { L71, L71.01 }\end{array}$ & ICPC code before 1-1-12 \\
\hline \multirow[t]{2}{*}{ Chronic sinusitis } & \multirow[t]{2}{*}{0.3} & Chronic sinusitis & R75.02 & ICPC code before 1-1-12 \\
\hline & & Acute Sinusitis & R75.01 en R75 & $\begin{array}{l}\text { ICPC code AND (recode OR connection } \\
\text { to episode) } \geq 3 \times / \text { year in 2011, 2012, } 2013 \\
\text { Years start with 1e ICPC code. Minimal } \\
29 \text { days between each episode. [45] }\end{array}$ \\
\hline Glomerulonephritis/nephrosis & 0.3 & Glomerulonephritis & U88 & ICPC code before 1-1-12 \\
\hline $\begin{array}{l}\text { Congenital cardiovascular } \\
\text { anomaly }\end{array}$ & 0.2 & $\begin{array}{l}\text { Congenital cardiovascular } \\
\text { anomaly }\end{array}$ & K73, K73.01, K73.02 & ICPC code before 1-1-12 \\
\hline Leukaemia & 0.2 & Leukaemia & B73 & ICPC code before 1-1-12 \\
\hline $\begin{array}{l}\text { Lymphoma/multiple myeloma/ } \\
\text { other blood cancer }\end{array}$ & 0.2 & $\begin{array}{l}\text { Lymphoma/multiple myeloma/ } \\
\text { other blood cancer }\end{array}$ & B74.01, B74 & ICPC code before 1-1-12 \\
\hline \multirow[t]{2}{*}{ Anaemia } & \multirow[t]{2}{*}{0.1} & Pernicous/folic acid anaemia & B81, B81.01, B81.02 & $\begin{array}{l}\text { ICPC code before 1-1-12 AND (recode } \\
\text { OR connection to episode) } 12 \text { months } \\
\text { after first ICPC [43] }\end{array}$ \\
\hline & & Haemolytic anaemia & $\begin{array}{l}\text { B78, B78.01, B78.02, } \\
\text { B78.03 }\end{array}$ & ICPC code before 1-1-12 \\
\hline Anorextia or bulimia & 0.1 & Anorexia nervosa & T06, T06.01, T06.02 & ICPC code before 1-1-12 \\
\hline Coeliakie & 0.1 & Coeliakie & D99.06 & ICPC code before 1-1-12 \\
\hline Endometrial cancer & 0.1 & Endometrial cancer & $X 77.01$ & ICPC code before 1-1-12 \\
\hline Metastases; unknown origin & 0.1 & Metastases; unknown origin & A79 & ICPC code before 1-1-12 \\
\hline Multiple sclerosis & 0.1 & MS (multiple sclerosis) & N86 & ICPC code before 1-1-12 \\
\hline Ovarian cancer & 0.1 & Ovarian cancer & $X 77.02$ & ICPC code before 1-1-12 \\
\hline Pancreatic cancer & 0.1 & Pancreatic cancer & D76 & ICPC code before 1-1-12 \\
\hline Testis cancer & 0.1 & Testis cancer & Y78.02 & ICPC code before 1-1-12 \\
\hline $\begin{array}{l}\text { Brain cancer (recall: Nervous } \\
\text { system cancer) }\end{array}$ & 0 & $\begin{array}{l}\text { Brain cancer (recall: Nervous } \\
\text { system cancer) }\end{array}$ & N74 & ICPC code before 1-1-12 \\
\hline HIV/AIDS & 0 & HIV; AIDS & B90, B90.01, B90.02 & ICPC code before 1-1-12 \\
\hline
\end{tabular}




\section{Appendix 2}

Table 7 List of comorbidity categories

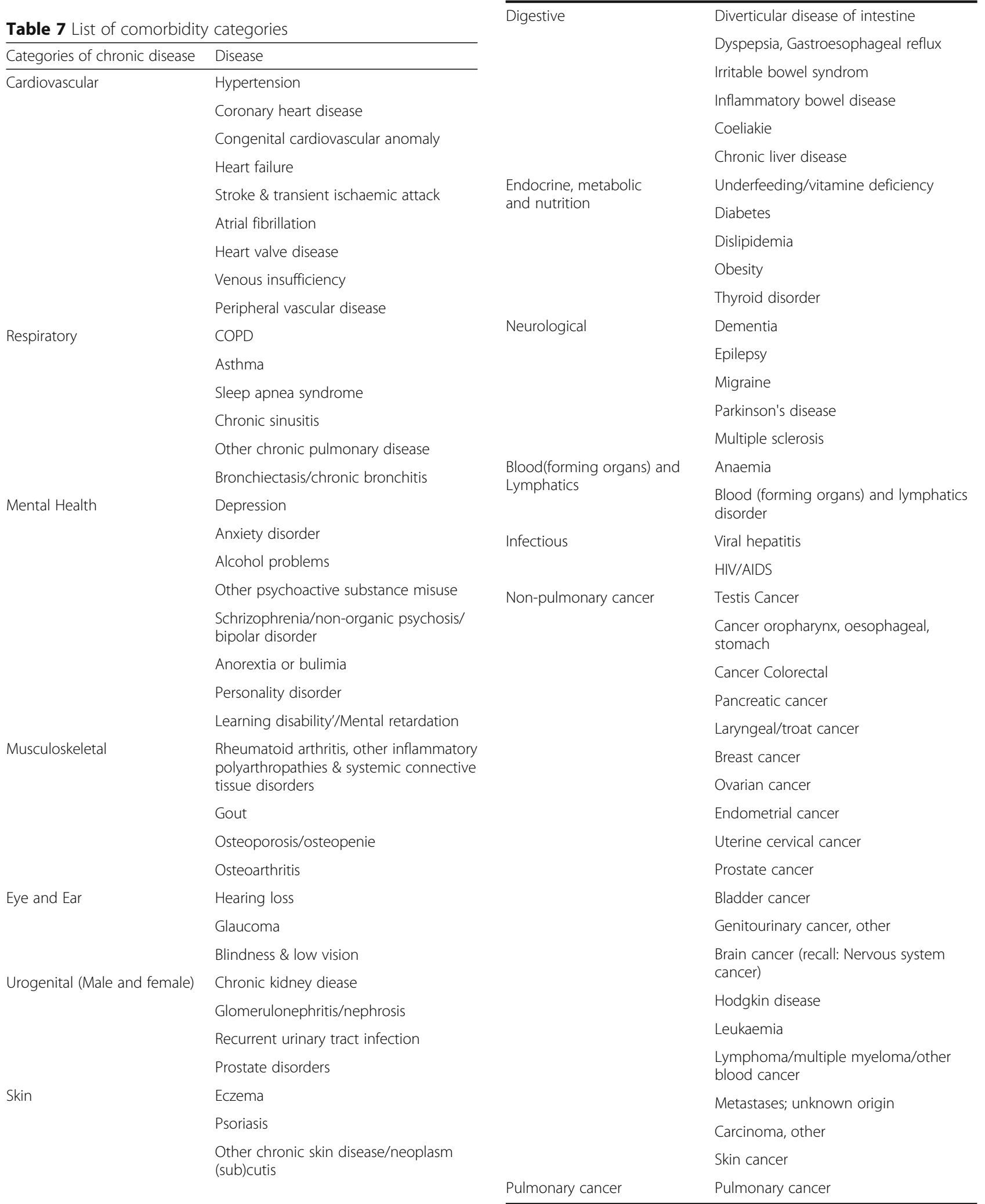

Table 7 List of comorbidity categories (Continued) 


\section{Appendix 3}

Table 8 Baseline characteristics of the initial population of all COPD patients, the patients who were lost to follow-up, and the patients with full follow-up

\begin{tabular}{|c|c|c|c|}
\hline & $\begin{array}{l}\text { All COPD patients } \\
(n=16,427)\end{array}$ & $\begin{array}{l}\text { Patients lost to follow-up } \\
(n=1,824)\end{array}$ & $\begin{array}{l}\text { Patients with full follow-up (study population) }{ }^{a} \\
(n=14,603)\end{array}$ \\
\hline \multicolumn{4}{|l|}{ Patient characteristics } \\
\hline Sex, male, n (\%) & $8,682(52 \cdot 9)$ & $933(51 \cdot 2)$ & $7,749(53 \cdot 1)$ \\
\hline Age at study baseline, years; mean (SD; range) & $66.9(11 \cdot 6 ; 40-111)$ & $70 \cdot 1(12 \cdot 0 ; 40-111)$ & $66.5(11.5 ; 40-110)^{\ddagger}$ \\
\hline \multicolumn{4}{|l|}{ Full dataset available (censored data), n (\%) } \\
\hline Full data available & $14,603(88 \cdot 7)$ & & \\
\hline Deceased & $541(3 \cdot 0)$ & $541(29 \cdot 7)$ & N/A \\
\hline Moved & $223(1 \cdot 3)$ & $223(12 \cdot 2)$ & N/A \\
\hline Nursing home & $36(0 \cdot 2)$ & $36(2 \cdot 0)$ & N/A \\
\hline Unknown & $1024(6 \cdot 2)$ & $1024(56 \cdot 1)$ & N/A \\
\hline \multicolumn{4}{|l|}{ Comorbidity data } \\
\hline Number of comorbid diseases ${ }^{b}$, mean (SD; range) & $3 \cdot 0(2 \cdot 3 ; 0-20)$ & $3.4(2 \cdot 5 ; 0-16)$ & $3 \cdot 0(2 \cdot 3 ; 0-20)^{\ddagger}$ \\
\hline \multicolumn{4}{|l|}{ Number of comorbid diseases categories ${ }^{\mathrm{b}}, \mathrm{n}(\%)$} \\
\hline 0 & $1,951(11.9)$ & $174(9.5)$ & $1,777(12 \cdot 2)$ \\
\hline 1 or 2 & $5,891(35.9)$ & $586(32 \cdot 1)$ & $5,305(36 \cdot 6)$ \\
\hline 3 or 4 & $4,797(29 \cdot 2)$ & $539(29 \cdot 6)$ & $4,258(29 \cdot 2)$ \\
\hline 5 and more & $3,788(23 \cdot 1)$ & $525(28.8)$ & $3,263(22 \cdot 3)^{\ddagger}$ \\
\hline \multicolumn{4}{|l|}{ Exacerbations data } \\
\hline Number of exacerbations, mean (SD; range) & $0.72(1.5 ; 0-15)^{c}$ & $0.46(1 \cdot 0 ; 0-11)^{c}$ & $0.75(1 \cdot 5 ; 0-15)$ \\
\hline
\end{tabular}

$S D$ standard deviation, N/A not applicable

${ }^{*} p<0.05,{ }^{\dagger} p<0.01,{ }^{\ddagger} p<0.001$

${ }^{a} p$-values displayed are calculated for the difference between patients lost to follow-up versus patients with full follow-up. Chi-square tests for categorized variables and independent $t$-tests for continuous variables. $p<0.05$ was considered statistically significant

bPresence of any type of comorbid disease was assessed at study baseline, i.e. 1 January 2012

'Mean number of exacerbations during the study period, 1 January 2012 - 31 December 2013. For the columns 'all COPD patients' and 'Patients lost to follow-up' these rates cannot be converted into annual rates because of incomplete observation time in the patients who were lost to follow-up

Baseline characteristics of the study population grouped by low ( $<2 /$ year) versus high $(\geq 2 / y e a r)$ exacerbation rate are reported in Table 1

\section{Abbreviations}

ATC: Anatomical therapeutic chemical; CKD: Chronic kidney disease; COPD: Chronic obstructive pulmonary disease; GERD: Gastroesophageal reflux disease; GP: General practitioner; ICPC: International classification of primary care; N/A: Not applicable; OR: Odds ratio; SD: Standard deviation; TIA: Transient ischemic attack; UK: United Kingdom; US: United States

\section{Acknowledgements}

The authors appreciate the statistical support provided by Reinier Akkermans.

\section{Funding}

GlaxoSmithKline funded the study with a research grant. The sponsor was not involved in the execution of the study, interpretation of the results, or the writing of this paper. The corresponding author had full access to all data and the final responsibility to submit for publication.

\section{Availability of data and materials}

Please contact author for data requests.

\section{Authors' contributions}

TRS initiated the study. JAMW, EM, JFMB, WT, JWHK and TRS designed the study. JAMW, EM and TRS analysed and interpreted data. JAMW and TRS wrote the initial version of the paper. JAMW, EM, JFMB, JWHK and TRS revised the report. All authors read and approved the final manuscript.

\section{Competing interests}

The authors declare that they have no competing interests.

\section{Consent for publication}

Not applicable.

\section{Ethics approval and consent to participate}

In the Netherlands, all patients are listed with a general practitioner (GP) and have access to specialized healthcare through this GP. For this database study, approval of an ethics committee was not required.

\section{Author details}

${ }^{1}$ Department of Primary and Community Care, Radboud University Medical Center, 117-ELG, Geert Grooteplein Noord 21, Nijmegen 6525 EZ, The Netherlands. ${ }^{2}$ Department of General Practice, Groningen Research Institute for Asthma and COPD (GRIAC), University Medical Center Groningen, University of Groningen, HPC FA21, Antonius Deusinglaan 1, Groningen 9713 AV, The Netherlands.

Received: 24 September 2016 Accepted: 18 January 2017 Published online: 06 February 2017 


\section{References}

1. Barnett K, Mercer SW, Norbury M, Watt G, Wyke S, Guthrie B. Epidemiology of multimorbidity and implications for health care, research, and medical education: a cross-sectional study. Lancet (London, England). 2012; 380(9836):37-43

2. From the Global Strategy for the Diagnosis, Management and Prevention of COPD, Global Initiative for Chronic Obstructive Lung Disease (GOLD). 2016. Available from: http://www.goldcopd.org/. Accessed 16 Jan 2017.

3. van Manen JG, IJzermans CJ, Bindels PJ, van der Zee JS, Bottema BJ, Schade E. Prevalence of comorbidity in patients with a chronic airway obstruction and controls over the age of 40. J Clin Epidemiol. 2001;54(3):287-93.

4. Negewo NA, McDonald VM, Gibson PG. Comorbidity in chronic obstructive pulmonary disease. Respir Invest. 2015;53(6):249-58.

5. Putcha N, Drummond MB, Wise RA, Hansel NN. Comorbidities and chronic obstructive pulmonary disease: prevalence, influence on outcomes, and management. Semin Respir Crit Care Med. 2015;36(4):575-91.

6. Wijnhoven HA, Kriegsman DM, Hesselink AE, de Haan M, Schellevis FG. The influence of co-morbidity on health-related quality of life in asthma and COPD patients. Respir Med. 2003;97(5):468-75.

7. Chen W, Thomas J, Sadatsafavi M, FitzGerald JM. Risk of cardiovascular comorbidity in patients with chronic obstructive pulmonary disease: a systematic review and meta-analysis. Lancet Respir Med. 2015;3(8):631-9.

8. Garcia-Olmos L, Alberquilla A, Ayala V, Garcia-Sagredo P, Morales L, Carmona $\mathrm{M}$, et al. Comorbidity in patients with chronic obstructive pulmonary disease in family practice: a cross sectional study. BMC Fam Pract. 2013;14:11.

9. Putcha N, Puhan MA, Drummond MB, Han MK, Regan EA, Hanania NA, et al. A simplified score to quantify comorbidity in COPD. PLoS One. 2014;9(12):e114438.

10. Divo M, Cote C, de Torres JP, Casanova C, Marin JM, Pinto-Plata V, et al. Comorbidities and risk of mortality in patients with chronic obstructive pulmonary disease. Am J Respir Crit Care Med. 2012;186(2):155-61.

11. de Torres JP, Casanova C, Marin JM, Pinto-Plata V, Divo M, Zulueta JJ, et al, Prognostic evaluation of COPD patients: GOLD 2011 versus BODE and the COPD comorbidity index COTE. Thorax. 2014;69(9):799-804.

12. Okkes IM, Becker HW, Bernstein RM, Lamberts $H$. The March 2002 update of the electronic version of ICPC-2. A step forward to the use of ICD-10 as a nomenclature and a terminology for ICPC-2. Fam Pract. 2002;19(5):543-6.

13. WHO Collaborating Centre for Drug Statistics Methodology. 2015. Available from: http://www.whocc.no/. Accessed 16 Jan 2017.

14. Luijks $H$, Schermer $T$, Bor $H$, van Weel $C$, Lagro-Janssen $T$, Biermans $M$, et al. Prevalence and incidence density rates of chronic comorbidity in type 2 diabetes patients: an exploratory cohort study. BMC Med. 2012;10:128.

15. Snoeck-Stroband JB, Schermer TRJ, Van Schayck CP, Muris JW, Van der Molen T, In 't Veen JCCM, Chavannes NH, Broekhuizen BDL, Barnhoorn MJM, Smeele I, Geijer RMM, Tuut MK. NHG guideline COPD (third revision). Huisarts Wet. 2015;58(4):198-211.

16. Seemungal TA, Donaldson GC, Bhowmik A, Jeffries DJ, Wedzicha JA. Time course and recovery of exacerbations in patients with chronic obstructive pulmonary disease. Am J Respir Crit Care Med. 2000:161(5):1608-13.

17. Frei A, Muggensturm P, Putcha N, Siebeling L, Zoller M, Boyd CM, et al. Five comorbidities reflected the health status in patients with chronic obstructive pulmonary disease: the newly developed COMCOLD index. Clin Epidemiol. 2014;67(8):904-11.

18. Rutten FH, Cramer MJ, Grobbee DE, Sachs AP, Kirkels JH, Lammers JW, et al. Unrecognized heart failure in elderly patients with stable chronic obstructive pulmonary disease. Eur Heart J. 2005;26(18):1887-94.

19. Almagro P, Cabrera FJ, Diez J, Boixeda R, Alonso Ortiz MB, Murio C, et al. Comorbidities and short-term prognosis in patients hospitalized for acute exacerbation of COPD: the EPOC en Servicios de medicina interna (ESMI) study. Chest. 2012;142(5):1126-33

20. Xu W, Collet JP, Shapiro S, Lin Y, Yang T, Platt RW, et al. Independent effect of depression and anxiety on chronic obstructive pulmonary disease exacerbations and hospitalizations. Am J Respir Crit Care Med. 2008;178(9): 913-20.

21. Kruis AL, Stallberg B, Jones RC, Tsiligianni IG, Lisspers K, van der Molen T, et al. Primary care COPD patients compared with large pharmaceuticallysponsored COPD studies: an UNLOCK validation study. PLoS One. 2014;9(3): e90145.

22. Ingebrigtsen TS, Marott JL, Nordestgaard BG, Lange P, Hallas J, Vestbo J. Statin use and exacerbations in individuals with chronic obstructive pulmonary disease. Thorax. 2015;70(1):33-40.
23. Chan MC, Lin CH, Kou YR. Hyperlipidemia in COPD is associated with decreased incidence of pneumonia and mortality a nationwide health insurance data based retrospective cohort study. Int J Chron Obstruct Pulmon Dis. 2016;11:1053-9.

24. de Vries M, Berendsen AJ, Bosveld HE, Kerstjens HA, van der Molen T. COPD exacerbations in general practice: variability in oral prednisolone courses. BMC Fam Pract. 2012;13:3.

25. Lee AL, Goldstein RS. Gastroesophageal reflux disease in COPD: links and risks. Int J Chron Obstruct Pulmon Dis. 2015;10:1935-49.

26. Price D, West D, Brusselle G, Gruffydd-Jones K, Jones R, Miravitlles M, et al. Management of COPD in the UK primary-care setting: an analysis of real-life prescribing patterns. Int J Chron Obstruct Pulmon Dis. 2014:9:889-904

27 James GD, Donaldson GC, Wedzicha JA, Nazareth I. Trends in management and outcomes of COPD patients in primary care, 2000-2009: a retrospective cohort study. NPJ Prim Care Respir Med. 2014;24:14015

28. Jones PW, Nadeau G, Small M, Adamek L. Characteristics of a COPD population categorised using the GOLD framework by health status and exacerbations. Respir Med. 2014;108(1):129-35.

29. Lange P, Tottenborg SS, Sorknaes AD, Andersen JS, Sogaard M, Nielsen H, et al. Danish Register of chronic obstructive pulmonary disease. Clin Epidemiol. 2016:8:673-8

30. Triest FJ, Franssen FM, Spruit MA, Groenen MT, Wouters EF, Vanfleteren LE. Poor agreement between chart-based and objectively identified comorbidities of COPD. Eur Respir J. 2015;46(5):1492-5.

31. Vanfleteren LE, Franssen FM, Uszko-Lencer NH, Spruit MA, Celis M, Gorgels AP, et al. Frequency and relevance of ischemic electrocardiographic findings in patients with chronic obstructive pulmonary disease. Am J Cardiol. 2011;108(11):1669-74.

32. Dijk WD, Bemt L, Haak-Rongen S, Bischoff E, Weel C, Veen JC, et al. Multidimensional prognostic indices for use in COPD patient care. A systematic review. Respir Res. 2011;12:151.

33. Jones RC, Donaldson GC, Chavannes NH, Kida K, Dickson-Spillmann M, Harding S, et al. Derivation and validation of a composite index of severity in chronic obstructive pulmonary disease: the DOSE Index. Am J Respir Crit Care Med. 2009:180(12):1189-95.

34. Rolink M, van Dijk W, van den Haak-Rongen S, Pieters W, Schermer T, van den Bemt L. Using the DOSE index to predict changes in health status of patients with COPD: a prospective cohort study. Prim Care Respir J. 2013:22(2):169-74.

35. Numans ME, De Wit NJ, Dirven JAM, Heemstra-Borst CG, Hurenkamp GJB, Scheele ME, Burgers JS, Geijer RMM, De Jongh E. NHG guideline Stomach complaints (third revision). Huisarts Wet. 2013;56:26-3.

36. Smeele I, Barnhoorn MJM, Broekhuizen BDL, Chavannes NH, In 't Veen JCCM, Van der Molen T, Muris JW, Van Schayck O, Schermer TRJ, SnoeckStroband JB, Geijer RMM, Tuut MK. NHG-Werkgroep Astma bij volwassenen en COPD. [NHG guideline Asthma in adults (third revision)]. Huisarts Wet. 2015;58(3):142-54

37. Van Weel-Baumgarten EM, Van Gelderen MG, Grundmeijer HGLM, LichtStrunk E, Van Marwijk HWJ, Van Rijswijk HCAM, Tjaden BR, Verduijn M, Wiersma T, Burgers JS, Van Avendonk MJP, Van der Weele GM. [NHG guideline Depression (second revision). Huisarts Wet. 2012;55(6):252-9.

38. Spijker J, Bockting CLH, Meeuwissen JAC, Vliet IM V, Emmelkamp PMG, Hermens MLM, Balkom ALJM V, namens de Werkgroep Multidisciplinaire richtlijnontwikkeling Angststoornissen/Depressie. Multidisciplinaire richtlijn Depressie (Derde revisie). Richtlijn voor de diagnostiek, behandeling en begeleiding van volwassen patiënten met een depressieve stoornis. Utrecht: Trimbos-instituut; 2013.

39. Hassink-Franke LJA, Terluin B, Van Heest FB, Hekman J, Van Marwijk HWJ, Van Avendonk MJP. [NHG guideline Anxiety (second revision)]. Huisarts Wet. 2012;55(2):68-77.

40. Van Hof N, Balak FSR, Apeldoorn L, De Nooijer HJ, Vleesch Dubois V. Van Rijn-van Kortenhof. [NHG guideline Ulcus cruris venosum (second revision)]. Huisarts Wet. 2010:53(6):321-33.

41. Van Pinxteren B, Knottnerus BJ, Geerlings SE, Visser HS, Klinkhamer S, Van der Weele GM, Verduijn MM, Opstelten W, Burgers JS, Van Asselt KM. [NHGguideline Urinary tract infections (third revision)]. Huisarts Wet. 2013;56(6): 270-80.

42. Janssens HJEM, Lagro HAHM, Van Peet PG, Gorter KJ, Van der Pas P, Van der Paardt M, Woutersen-Koch H. [NHG guideline osteoarthritis (first version)]. Huisarts Wet. 2009;52(9):439-53. 
43. Bouma M, Burgers J, Drost B, Den Elzen WPJ, Luchtman T, OosterhuisWP, Woutersen-Koch H, Van Wijk M; NHG-werkgroep Anemie. [NHG guideline anemia (first revision)]. Huisarts Wet. 2014;57(10):528-36.

44. Dekker F, Van Duijn NP, Ongering JEP, Bartelink MEL, Boelman L, Burgers JS, Bouma M, Kurver MJ. [NHG guideline Headache (third revision)]. Huisarts Wet. 2014;57(1):20-31.

45. Venekamp RP, De Sutter A, Sachs A, Bons SCS, Wiersma TJ, De Jongh E. [NHG guideline Acute rhinosinusitis (third revision)]. Huisarts Wet. 2014; 57(10):537.

Submit your next manuscript to BioMed Central and we will help you at every step:

- We accept pre-submission inquiries

- Our selector tool helps you to find the most relevant journal

- We provide round the clock customer support

- Convenient online submission

- Thorough peer review

- Inclusion in PubMed and all major indexing services

- Maximum visibility for your research

Submit your manuscript at www.biomedcentral.com/submit
Biomed Central 